\title{
Andrzej Tamborski
}

Wrocław

\section{Przejęcie administracji celnej w województwie poznańskim w latach 1920-1921}

\begin{abstract}
Abstrakt: Art. 256 traktatu wersalskiego sankcjonował prawo państw sukcesyjnych do przejęcia całego majątku państwowego Rzeszy i państw niemieckich, znajdującego się na obszarach odstąpionych przez nie nowo powstałym państwom. Techniczną stronę wykonania tego postanowienia na terytorium byłej dzielnicy pruskiej regulowała w głównej mierze podpisana w Berlinie 25 XI 1919 r. polsko-niemiecka Umowa o oddaniu zarządu cywilnego. Akcja przejmowania państwowej własności celnej, zainicjowana w województwie poznańskim już w styczniu $1920 \mathrm{r}$. dobiegła końca w końcu stycznia 1921 r.
\end{abstract}

Słowa kluczowe: II Rzeczpospolita, celnictwo, administracja państwowa, województwo poznańskie, traktat wersalski.

Abstract: Under article 256 of the Treaty of Versailles, the states to which German territory was ceded, acquired all property and possessions situated therein belonging to the German Empire or to the German States. The technical part of this resolution for the former Prussian partition was regulated mainly by the Polish-German Agreement ceding the civilian administration signed in Berlin on 25 November 1919. The taking over of the state customs properties, initiated in Poznan province in January 1920, was concluded by the end of January of the following year.

Keyw ords: Second Republic of Poland, customs officer, state administration, Poznań province, Treaty of Versailles.

Na obszarze ziem polskich zaboru pruskiego na początku XX w. przenikały się dwa odrębne systemy skarbowe, uwzględniające w swym modelu organizacyjnym związkowy charakter Cesarstwa Niemieckiego i opierające się na odmiennych podstawach dochodowych: Rzeszy Niemieckiej i Królestwa 
Prus. Pierwszy z nich bazowal, zgodnie z brzmieniem art. 38 Konstytucji Rzeszy Niemieckiej z 1871 r., na wpływach pochodzacych z ceł i podatków konsumpcyjnych (od krajowej soli, tabaki, wódki, piwa, cukru i syropu) zasilajacych kasę Rzeszy ${ }^{1}$. Artykuł 35 wspomnianej ustawy zasadniczej upoważniał Rzeszę do wydawania aktów prawnych w zakresie celnictwa, opodatkowania powyższych produktów, ochrony danin konsumpcyjnych przed defraudacjami i zabezpieczenia wspólnej granicy celnej na obszarach wolnocłowych ${ }^{2}$. Nad przestrzeganiem przez państwa związkowe ustawowego trybu postępowania i należytym wykonywaniem ustawodawstwa celno-podatkowego Rzeszy czuwali przydzielani przez cesarza do prowincjonalnych władz skarbowych tzw. Pełnomocnicy Rzeszy dla Ceł i Podatków (Reichsbevolmächtigte für Zölle und Steuern) i delegowani przez niego do głównych urzędów celnych i podatkowych $\mathrm{w}$ terenie kontrolerzy stacyjni (Stationskontrolleure) ${ }^{3}$. Stanowisko pełnomocnika Rzeszy przy poznańskiej naddyrekcji ceł piastował w okresie 1910-1917 hamburski nadradca rejencyjny Otto Wittstein, z siedziba w Szczecinie. Funkcję kontrolera w prowincji poznańskiej pełnił w latach 1907-1914 saksoński nadrewizor celny Walter Ernst Lippert, z miejscem urzędowania w Poznaniu 4 .

Pobór oraz zarząd ceł i podatków pośrednich w Rzeszy Niemieckiej pozostawały w okresie 1871-1919 w kompetencji państw zwiąkowych. W Prusach wykonywano je pod naczelnym kierownictwem Ministerstwa Skarbu w Berlinie. W skład jego struktury organizacyjnej wchodził nieprzerwanie od 1877 r. Wydział Administracji Ceł i Podatków Pośrednich z generalnym dyrektorem na czele ${ }^{5}$. W związku ze zwrotem przez Rzeszę kosztów administracyjnych poboru i zarządu opisywanych danin konieczne było prowadzenie stosownych rozliczeń finansowych między nią a państwami związkowymi. Realizacją tego zadania ze strony pruskiej zajmowało się funkcjonujące przy powyższym wydziale Ministerstwa Skarbu Biuro Obrachunkowe Podatków Rzeszy 6 .

${ }^{1}$ Bundes-Gesetzblatt des Deutschen Bundes (dalej: BGB) 1871 No 16 Nr. 628. W budżecie Rzeszy Niemieckiej z 1913 r. wpływy z ceł i podatków pośrednich stanowiły 42,8\%; podatki stemplowy, spadkowy, obrotowy, od przyrostu wartości - 29\%; z przedsiębiorstw i własności - 28,2\% wszystkich dochodów skarbu państwa, zob. Księga pamiatkowa polskiej administracji skarbowej $w$ Wielkopolsce $i$ na Pomorzu, cz. 1, red. S. Obrzud, Poznań-Grudziądz 1929, s. 68.

${ }^{2}$ BGB 1871 No 16 Nr. 628.

${ }^{3}$ Ibidem, art. 36.

${ }^{4}$ Okresy urzędowania ustalono na podstawie niemieckich ksiag adresowych miasta Poznania z lat 1907-1917.

${ }_{5}^{5}$ Berliner Adreß-Buch für das Jahr 1877. Unter Benutzung amtlicher Quellen, Th. 4, Berlin 1877, s. 19; Berliner Adreßbuch 1918. Unter Benutzung amtlicher Quellen, Bd. II, Berlin 1918, s. 36.

${ }^{6}$ Berliner Adreßbuch 1918..., s. 36; B. Markowski, Administracja skarbowa $w$ Polsce, Warszawa 1931, s. 58. 
W pierwszej dekadzie XX w. zarząd celno-podatkowy w prowincjach państwa pruskiego poddano zmianom organizacyjnym. Zgodnie z $§ 1$ Najwyższego dekretu dotyczącego trybu urzędowania królewsko-pruskich władz celnych z 15 I 1908 r. zarząd ceł i podatków pośrednich prowadziły w miejsce dotychczas funkcjonujących prowincjonalnych dyrekcji podatków nowo powstałe naddyrekcje ceł (Oberzolldirektionen) ${ }^{7}$. Były to biurokratycznie zorganizowane zarządy tych danin, z prezydentami na czele, odpowiedzialne $\mathrm{w}$ swoim okręgu administracyjnym m.in. za należyte wykonywanie ustaw i przepisów celno-podatkowych, wydawanie koniecznych w tym celu zarzadzeń i orzekanie w drugiej instancji w sprawach odwołań od decyzji podległych im urzędów podatku stemplowego i spadkowego, głównych urzędów celnych i innych urzędów podporządkowanych tym ostatnim ${ }^{8}$. Naddyrekcja Ceł w Poznaniu, obejmująca swą działalnością obszar okręgów rejencyjnych bydgoskiego i poznańskiego, zaczęła funkcjonować z dniem 1 IV 1908 r. ${ }^{9}$

W dziedzinie celnictwa podlegały jej administrujace jednocześnie cłem, akcyzami i w ograniczonym zakresie kompetencyjnym podatkami stemplowym i spadkowym główne urzędy celne. Do ich zadań należało również wykonywanie nadzoru celno-skarbowego we własnych obwodach w sposób bezpośredni i przy pomocy podwładnych nadkontrolerów i dozorców celnych ${ }^{10}$. W latach 1908-1919 w prowincji poznańskiej funkcjonowało osiem głównych urzędów celnych z siedzibami w Bydgoszczy, Inowrocławiu, Lesznie, Poznaniu, Międzyrzeczu, Ostrowie Wlkp., Wrześni i Rogoźnie. W październiku 1908 r. podlegało im 79 nadkontroli celnych, w tym 10 przygranicznych i 69 zlokalizowanych w głębi obszaru celnego ${ }^{11}$. Głównym urzędom celnym podporządkowano także funkcjonujace w ich obwodach od 1 IV 1908 r. urzędy celne I i II klasy. Ich stan liczbowy w październiku tego roku wynosił ogółem 65, w tym 36 I klasy i 29 II klasy ${ }^{12}$. W zestawieniu urzędników celnych z 1914 r. pojawia się dodatkowo Urząd Celny w Nowym Tomyślu ${ }^{13}$. Ze względu na fakt niestwierdzenia w źródłach wypadków zakładania nowych urzędów celnych w późniejszym okresie należy przyjąć, że ich liczba w kolejnych latach działalności pruskiego zarządu celnego na badanym terytorium wynosiła najprawdopodobniej 66 .

Kluczowe dla polskiej racji stanu następstwo postanowień terytorialnych traktatu wersalskiego stanowiło zagadnienie likwidacji istniejacych dotychczas na obszarze byłej dzielnicy pruskiej stosunków zaborczych w dziedzinach administracji, skarbowości i życia gospodarczego. Postanowienia traktatu

\footnotetext{
${ }^{7}$ Preußische Gesetzsammlung, 1908, nr 12, poz. 10881.

${ }^{8}$ Ibidem, § 5 ust. 1, 2; Ksiega pamiatkowa..., s. 66.

${ }_{9}$ Amtsblatt der Königlichen Regierung zu Bromberg, 1908, nr 14, poz. 330.

${ }^{10}$ Księga pamiatkowa..., s. 83.

${ }^{11}$ Handbuch der Provinz Posen, Dritte Ausgabe, Posen 1909, s. 19-20.

12 Ibidem, s. 20, 21-26; Amtsblatt der Königlichen Regierung zu Bromberg, 1908, nr 14, poz. 330.

13 Archiwum Państwowe w Poznaniu (dalej: APP), Dyrekcja Ceł w Poznaniu 1919-1939 (dalej: DCP), sygn. 4, Zestawienie urzędników celnych z 1914 i 1922 r.
} 
pokojowego szły w sukurs tym potrzebom, sankcjonując w art. 256 prawo państw sukcesyjnych do przejęcia całego majątku państwowego Rzeszy i państw niemieckich, znajdującego się w obrębie terytoriów odstapionych przez te ostatnie nowym sukcesorom ${ }^{14}$. Ustawa z dnia 1 VIII 1919 r. o tymczasowym zarządzie byłej dzielnicy pruskiej przekazywała powyższe zadanie na tym obszarze kompetencji ministra byłej dzielnicy pruskiej ${ }^{15}$. Przepisy tego samego aktu prawnego pozostawiały w ręku wspomnianego organu władzy państwowej zwierzchnictwo służbowe władz i urzędów celnych oraz sprawowanie zarządu celnego na obszarze byłej dzielnicy pruskiej do czasu przekazania ich ministrowi skarbu w Warszawie, co nastapiło na podstawie uchwały Rady Ministrów z dnia 30 XII 1920 r. ${ }^{16}$

Wszelkie szczegółowe kwestie związane z zasadami i sposobem stwierdzania majątku państwowego na obszarach odstapionych Polsce przez Prusy, przekazywaniem go władzom polskim przez ustępujące organy niemieckie i obejmowaniem tegoż $\mathrm{w}$ polskie posiadanie regulowały stosowne postanowienia podpisanej w Berlinie 25 XI 1919 r. Umowy o wycofaniu wojsk z odstapionych obszarów i oddaniu zarządu cywilnego. Litera B układu, poświęcona w całości problematyce przejścia administracji cywilnej obszarów odstapionych w nowe uwarunkowania polityczne wytworzone przez traktat wersalski, normowała w cz. 1 zagadnienie przekazania Polsce władz i majątku państwowego, występujących na tychże terenach. W celu realizacji powyższych kwestii ustanowiono z obu zainteresowanych stron komisarzy poszczególnych szczebli (szczegółowych, generalnych, państwowych), określono ich zadania i sposób oddania zarządu ${ }^{17}$. Na mocy przepisów ustępu b) rozdz. III cz. 1 litery B umowy berlińskiej i podpisanego w Paryżu 8 I 1920 r. protokołu dodatkowego do niej strona niemiecka zobowiązała się do przekazania Polsce jednocześnie z nieruchomościami także państwowej własności ruchomej niezbędnej do dalszego prowadzenia zarządu w uporządkowany sposób, zgodnie z jej stanem inwentarzowym na 11 XI 1918 r. oraz wszystkich potrzebnych $\mathrm{w}$ tym celu akt ${ }^{18}$. Zamieszczony poniżej schemat przedstawia ostatecznie ukształtowaną w latach 1919-1920 strukturę organizacyjną polskich urzędów państwowych, odpowiedzialnych za przejęcie od władz niemieckich ruchomego i nieruchomego majątku państwowego, stanowiącego dotychczas własność pruskiej administracji celnej.

${ }_{14}$ Dziennik Ustaw (dalej: Dz.U.) 1920, nr 35, poz. 200; Z. Szczawiński, Likwidacja majątków niemieckich $w$ Polsce, Warszawa 1923, s. 1.

${ }_{15}$ Dziennik Praw Państwa Polskiego 1919, nr 64, poz. 385.

${ }^{16}$ Ibidem, art. 6b, 7; Archiwum Akt Nowych, Prezydium Rady Ministrów, cz. 1, t. XII, Protokół 121 posiedzenia Rady Ministrów Rzeczypospolitej Polskiej odbytego dnia 30 XII 1920 r., załącznik do punktu 12 obrad.

${ }_{17}$ Zbiór umów i układów zawartych między rzqdem polskim i niemieckim $w$ Berlinie $i$ w Paryżu w roku 1919 i w styczniu 1920, Poznań 1920, s. 28-32.

18 Ibidem, s. 30, 34. 
Schemat 1. Władze i urzędy polskie dla przejęcia zarządu celnego w latach 1920-1921

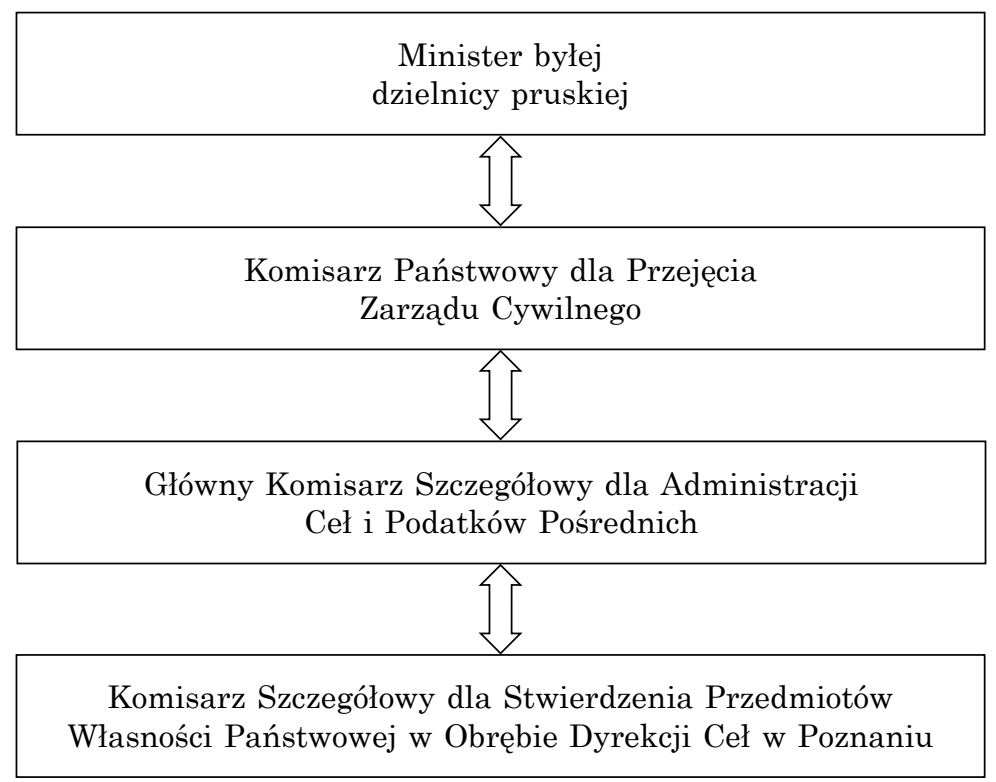

Źródło: APP, DCP, sygn. 15.

W styczniu 1920 r. Ministerstwo Byłej Dzielnicy Pruskiej mianowało ówczesnego wojewodę poznańskiego Witolda Celichowskiego Komisarzem Państwowym dla Przejęcia Zarządu Cywilnego w Częściach Prowincji Poznańskiej i Ślaskiej Odstapionych Polsce, upoważniając go zarazem do doboru komisarzy szczegółowych i generalnych ${ }^{19}$. Zakres jego czynności obejmował oddanie agend administracyjnych wychodzących poza terytorialny zakres działania komisarzy generalnych (starostów, landratów), rozstrzyganie powstałych między nimi różnic zdań, omawianie zagadnień zasadniczych i wyrażanie zgody na pobyt niemieckich komisarzy i ich personelu pomocniczego na polskim terytorium na okres dłuższy niż tydzień, jeśli oddanie zarządu cywilnego nie zakończyło się równocześnie $\mathrm{z}$ ewakuacją wojskowa terytoriów odstapionych ${ }^{20}$. Do innych uprawnień komisarza państwowego należało także ustalanie w porozumieniu ze swym niemieckim odpowiednikiem szczegółów akcji zdawczej oraz sposobu zakwaterowania niemieckich komisarzy zdawczych i ich personelu pomocniczego ${ }^{21}$. Zagadnieniem konfliktogennym i dodatkowo komplikującym współpracę obu zainteresowanych stron była kwestia ulokowania Biura Zdawczego Niemieckiej Administracji Ceł i Podatków Pośrednich. Strona niemiecka z ministrem skarbu Rzeszy na czele

\footnotetext{
19 „Dziennik Poznański” 1920, nr 12, s. 3.

${ }^{20}$ Zbiór umów i układów..., s. 29, 30.

${ }^{21}$ Ibidem, s. 31.
} 
dążyła za pośrednictwem komisarza państwowego w Pile do zainstalowania komisarza zdawczego w jego dotychczasowych pomieszczeniach służbowych w gmachu Naddyrekcji Ceł w Poznaniu, gdzie znajdowały się niezbędne akta, wykazy, kwity i księgi kasowe, konieczne do prowadzenia rozliczeń dochodów i wydatków państwowych ${ }^{22}$. Po konsultacji prezydenta dyrekcji ceł Radwańskiego z wojewoda Celichowskim postanowiono ustosunkować się negatywnie do niemieckiego wniosku, powołując się na brak podstaw prawnych do istnienia osobnych biur likwidacyjnych poza Generalnym Urzędem Zdawczym w Pile, uznano tym samym wprost za niedopuszczalne urządzanie ich $\mathrm{w}$ gmachach polskiej administracji ${ }^{23}$. Pieczy komisarza państwowego powierzono także zgromadzenie całego zasobu protokolarnego stwierdzonej własności państwowej poszczególnych gałęzi administracji, przedkładanego mu przez głównych komisarzy szczegółowych ${ }^{24}$. Opisywany urzędnik sprawował ogólny nadzór służbowy nad tymi ostatnimi i stanowił wraz ze swoim niemieckim odpowiednikiem instancję odwoławczą w razie zaistnienia kwestii spornych między obustronnymi głównymi komisarzami szczegółowymi ${ }^{25}$. Rozpatrywał wnioski niemieckiego komisarza zdawczego o udostępnianie i wydawanie akt oraz wszelkiej dokumentacji własnościowej władz i urzędów celnych (zwoje przynależności, inwentarze ruchomości, spisy inwentarza itp.), akt dotyczacych podatku spadkowego, a także decydował o dopuszczeniu do użytku służbowego protokołów do stwierdzania państwowej własności celnej, wydając w uzasadnionych przypadkach dyspozycje związane $\mathrm{z}$ modyfikacją ich treści ${ }^{26}$.

${ }^{22}$ APP, Reichs- und Staatskommissar für die Überleitung an Polen in Schneidemühl (dalej: St.K.), sygn. 30, Pismo Ministra Skarbu Rzeszy nr IV.Wa.3733. do komisarza państwowego w Pile, 30 I 1920 r.; APP, DCP, sygn. 15, Pismo Gesch. nr 110/20 Komisarza Zdawczego Niemieckiego Zarządu Ceł i Podatków Pośrednich do prezydenta Naddyrekcji Ceł w Poznaniu, 6 III 1920 r.; ibidem, Pismo Gesch. nr 110/20 Komisarza Zdawczego Niemieckiego Zarządu Ceł i Podatków Pośrednich do prezydenta Naddyrekcji Ceł w Poznaniu, 9 IV 1920 r.

${ }^{23}$ Ibidem, DCP, sygn. 15, Pismo Nr. I. 1719 prezydenta Dyrekcji Ceł w Poznaniu do Komisarza Państwowego dla Objęcia Zarządu Cywilnego na Obszarze b. Prowincji Poznańskiej i Górnego Śląska, 17 III 1920 r.; ibidem, Pismo Nr. dz. 185.20.K.P. komisarza państwowego do prezydenta Dyrekcji Ceł w Poznaniu, 30 III 1920 r.

${ }^{24}$ Ibidem, Pismo l. dz. 109/20 K.P. komisarza państwowego do głównych komisarzy szczegółowych, 8 III $1920 \mathrm{r}$.

${ }^{25}$ Ibidem, Pismo l. dz. 327/20 K.P. komisarza państwowego do prezydenta Naddyrekcji Cła dr. Radwańskiego, 30 IV 1920 r.; ibidem, Pismo l. dz. 327/20 K. P. komisarza państwowego do prezydenta Naddyrekcji Cła dr. Radwańskiego, 22 IV 1920 r.

${ }^{26}$ Ibidem, Pismo nr I 3597 komisarza państwowego wojewody do Dyrekcji Ceł w Poznaniu w sprawie oceny wzoru formularza dla stwierdzenia państwowej własności, b.d. Data 7 czerwca $1920 \mathrm{r}$. podana w dokumencie dotyczy daty dołączenia go do akt sprawy, samo pismo jest starsze, ponieważ wojewoda poznański pełnił obowiązki komisarza państwowego do 19 V 1920 r. Numer pisma jest sygnatura nadaną mu przez kancelarię Dyrekcji Ceł w Poznaniu, gdyż korespondencja komisarza państwowego posiadała inną numerację, co jednak nie wpływa na autentyczność treści i podpisu na dokumencie; ibidem, Pismo 
Aby scentralizować w jednym ręku całość spraw związanych z likwidacja niemieckiej administracji cywilnej na obszarach byłego zaboru pruskiego odstapionych Polsce i odciążyć z funkcji komisarza państwowego wojewodów poznańskiego i pomorskiego, minister byłej dzielnicy pruskiej powołał na to stanowisko 19 V 1920 r. dotychczasowego ich zastępcę na tym urzędzie, radce ministerialnego Wiktora Hinzego ${ }^{27}$. W jego akcie nominacyjnym unormowano kwestię podległości służbowej komisarza państwowego, podporządkowując go ministrowi byłej dzielnicy pruskiej poprzez Biuro Prezydialne ${ }^{28}$. W okresie od maja 1920 r. do stycznia 1921 r. siedziba komisarza państwowego znajdowała się w kilku różnych punktach Poznania. Do 1 VII 1920 r. urzędował w gmachu województwa, po czym z tym dniem jego biuro zostało przeniesione do budynku Dyrekcji Poczt przy ul. Wjazdowej 12, pokój $83^{29}$. Wreszcie w styczniu 1921 r. jego siedziba mieściła się przy Wałach Zygmunta Augusta $8^{30}$.

Pismem z 8 III 1920 r. komisarz państwowy Celichowski ustanowił dla zarządu ceł urząd głównego komisarza szczegółowego celem stwierdzenia przedmiotów własności lub posiadania państwa znajdujacych się na obszarze byłej prowincji poznańskiej opanowanym przez Polskę przed wejściem w życie postanowień traktatu pokojowego ${ }^{31}$. Zgodnie z treścia powyższego dokumentu wspomniane stanowisko miało przypaść w udziale naczelnikowi odnośnej gałęzi administracji, którym był w tym wypadku prezydent naddyrekcji ceł Stefan

1. dz. 917/20 K.P. Komisarza Państwowego dla Przejęcia Zarządu Cywilnego na Odstapionych Polsce Częściach b. Dzielnicy Pruskiej do prezydenta Dyrekcji Ceł w Poznaniu, 6 VII 1920 r.; ibidem, Pismo nr I 3743 prezydenta Dyrekcji Ceł w Poznaniu do komisarza państwowego, 18 VI 1920 r.; ibidem, Pismo nr I 3827 Dyrekcji Ceł w Poznaniu do komisarza państwowego w Poznaniu, czerwiec 1920 r.; ibidem, Pismo G 330 Urzędu Opłat Stemplowych i Podatku Spadkowego do dyrekcji ceł, 30 VIII 1920 r.; ibidem, Pismo 1451/20 K.P. komisarza państwowego do prezydenta Dyrekcji Ceł w Poznaniu, 28 VII 1920 r.; ibidem, Pismo l. dz. 1360/20 K.P. Komisarza Państwowego dla Przejęcia Zarządu Cywilnego na Odstapionych Polsce Częściach b. Dzielnicy Pruskiej do Dyrekcji Ceł w Poznaniu, 23 VII $1920 \mathrm{r}$.

${ }^{27}$ Ibidem, Odpis pisma 1. dz. 5a 2329/2330/20 Departamentu Spraw Wewnętrznych Ministerstwa Byłej Dzielnicy Pruskiej do Departamentu Skarbu Ministerstwa byłej Dzielnicy Pruskiej, 19 V 1920 r.; ibidem, Odpis pisma l. dz. 5a 2329/2330/20 Departamentu Spraw Wewnętrznych Ministerstwa Byłej Dzielnicy Pruskiej do Biura Prezydialnego Ministerstwa Byłej Dzielnicy Pruskiej, 19 V 1920 r.

${ }^{28}$ Zob. przypis 39.

${ }^{29}$ Ibidem, Pismo l. dz. 985/20 Komisarza Państwowego dla Przejęcia Zarządu Cywilnego na Odstapionych Polsce Częściach b. Dzielnicy Pruskiej do prezydenta Dyrekcji Ceł dr. Radwańskiego, 4 VII 1920 r.

${ }^{30}$ Ibidem, Pismo l. dz. 5408/21 K.P. Komisarza Państwowego dla Przejęcia Zarządu Cywilnego do głównego komisarza szczegółowego dr. Radwańskiego, 27 I 1921 r.

${ }^{31}$ Ibidem, Pismo l. dz. 109/20 K.P. Komisarza Państwowego dla Objęcia Zarządu Cywilnego na Obszarze b. Prowincji Poznańskiej i Górnego Śląska do Panów Głównych Komisarzy Szczegółowych, 8 III 1920 r. 
Radwański. W celu protokolarnego odnotowania na miejscu wszystkich przedmiotów własności państwa, należących do fiskusa celnego, przysługiwało mu prawo mianowania komisarza szczegółowego. Główny komisarz szczegółowy rozstrzygał w porozumieniu ze swoim niemieckim odpowiednikiem wszelkie kwestie sporne zachodzące między obustronnymi komisarzami szczegółowymi ${ }^{32}$. Gromadził cały zasób protokolarny stwierdzonej własności celnej i przekazywał go komisarzowi państwowemu. Odpowiadał za sporządzenie wykazu akt będących w posiadaniu władz niemieckich, których rewindykacja okazała się niezbędna do dalszego funkcjonowania polskiej administracji celnej ${ }^{33}$.

13 III 1920 r. odbyła się w sali posiedzeń województwa poznańskiego konferencja na temat zasad obowiąujaccych głównych komisarzy szczegółowych przy stwierdzaniu własności państwowej ${ }^{34}$. W jej trakcie poddano pod dyskusję kilka spraw natury organizacyjnej, poruszonych w piśmie wojewody Celichowskiego z 8 marca tego roku. Zaaprobowano i ustalono, że komisarz państwowy powołuje podległych sobie głównych komisarzy szczegółowych w osobach naczelników miejscowych władz państwowych. Usankcjonowano prawo tych ostatnich do wyznaczania ze swej strony komisarzy do protokolarnego stwierdzenia własności państwowej przy współudziale niemieckich pełnomocników. Głównych komisarzy szczegółowych upoważniono także do określania czasu i miejsca prac polskiego i niemieckiego komisarza szczegółowego. Postanowiono nie udostępniać Niemcom biur do prac przedwstępnych ani wydawać żadnych akt za wyjątkiem zbędnych i personalnych ${ }^{35}$.

W kwietniu 1920 r. przygotowania do wszczęcia akcji przejmowania zarządu cywilnego weszły w decydująca fazę. Wojewoda Celichowski przedstawił niemieckiemu komisarzowi państwowemu w Pile wykaz 21 głównych komisarzy szczegółowych, upoważnionych przez stronę polską do przejęcia wszystkich gałęzi administracji, funkcjonujących w byłej prowincji poznańskiej ${ }^{36}$. Uwzględniono w nim również prezydenta Dyrekcji Ceł w Poznaniu dr. S. Radwańskiego, którego oficjalne mianowanie na urząd Głównego

32 Ibidem, Pismo l. dz. 327/20 K.P. Komisarza Państwowego dla Objęcia Zarządu Cywilnego na Województwo Poznańskie do prezydenta Naddyrekcji Cła dr. Radwańskiego, 22 IV 1920 r.

${ }^{33}$ Ibidem, Pismo l. dz. 1328/20 K.P. Komisarza Państwowego dla Przejęcia Zarządu Cywilnego na Odstapionych Polsce Częściach b. Dzielnicy Pruskiej do głównego komisarza szczegółowego Radwańskiego w sprawie stwierdzenia akt potrzebnych do dalszego prowadzenia administracji, 20 VII 1920 r.; ibidem, Pismo l. dz. 1328/20 K.P. Komisarza Państwowego dla Przejęcia Zarządu Cywilnego do głównego komisarza szczegółowego prezydenta dyrekcji ceł Radwańskiego w Poznaniu, 27 IX 1920 r.

${ }^{34}$ Ibidem, Relacja służbowa nadsekretarza celnego Stanisława Mikołajewskiego z przebiegu konferencji zwołanej na 13 III 1920 r. przez Komisarza Państwowego dla Objęcia Zarządu na Obszarze b. Prowincji Poznańskiej i Górnego Śląska.

${ }^{35}$ Ibidem.

${ }^{36}$ APP, St.K., sygn. 1, Załącznik do pisma nr dz. 326/20 K.P. komisarza państwowego wojewody do komisarza państwowego w Pile, 20 IV 1920 r. 
Komisarza Szczegółowego dla Zarządu Ceł w Obrębie Województwa Poznańskiego nastapiło 30 IV 1920 r. ${ }^{37}$ Stosownie do panujacego $\mathrm{w}$ tym czasie stanu polsko-niemieckich stosunków umownych w badanej problematyce polski komisarz państwowy zlecił głównym komisarzom szczegółowym w kwietniu 1920 r. podjęcie prac mających na celu protokolarne stwierdzenie wszystkich przedmiotów własności lub posiadania państwa występujących w częściach obszarów odstapionych prowincji poznańskiej, zajętych przez Polskę przed 10 I 1920 r., i pieniężne rozliczenie dochodów i wydatków państwowych na wspomnianych terenach ${ }^{38}$. W celu wykonania pierwszego z wyżej wymienionych zadań, połączonego z jednoczesnym przejmowaniem z rąk niemieckich władz i urzędów celnych, prezydent Radwański mianował w maju 1920 r. komisarzem szczegółowym urzędnika dyrekcji ceł Michała Joniaka i upoważnił go do przeprowadzenia jeszcze $\mathrm{w}$ tym samym miesiącu stosownych prac przy urzędach celnych we Wronkach, Szamotułach, Buku, Gnieźnie, Środzie i Stęszewie ${ }^{39}$. Na poczatku czerwca 1920 r. właściwość terytorialna działalności komisarza szczegółowego rozciagała się na cały okręg administracyjny Dyrekcji Ceł w Poznaniu ${ }^{40}$.

Zgodnie z postanowieniami umowy paryskiej podpisanej 9 I 1920 r. przyjęto, że 1 X 1919 r. stanie się dniem rozrachunku finansowego Polski i Niemiec. Tym samym wszystkie dochody i wydatki państwowe pobrane lub poczynione na terytoriach odstapionych przed tym terminem przechodziły na rachunek Niemiec, pozostałe, posiadające termin płatności po tym dniu, zostały zapisane na konto Polski ${ }^{41}$. Rozrachunek dochodów i wydatków celnych na obszarze byłej prowincji poznańskiej prowadzono ze strony polskiej w głównej kasie celnej dyrekcji, rozliczając je osobno na rachunek Niemiec ${ }^{42}$. Stan zachowania źródeł nie pozwala przytoczyć ani konkretnych sum pieniężnych, ani zorientować

${ }^{37}$ Ibidem, DCP, sygn. 15, Pismo nominacyjne 1. dz. 327/20 K.P. komisarza państwowego do prezydenta naddyrekcji cła dra Radwańskiego, 30 IV 1920 r.

38 Ibidem, Pismo l. dz. 327/20 K.P. komisarza państwowego wojewody do prezydenta naddyrekcji cła dra Radwańskiego, 22 IV 1920 r.

${ }^{39}$ Ibidem, Pismo Nr. I. 2861. Głównego Komisarza Szczegółowego dla Administracji Ceł i Podatków Pośrednich w sprawie mianowania Michała Joniaka Komisarzem Szczegółowym dla Stwierdzenia Przedmiotów Własności Państwowej w urzędach celnych we Wronkach, Szamotułach, Buku, Gnieźnie i Środzie, 10 V 1920 r.; ibidem, Pismo Nr I 2861 Głównego Komisarza Szczegółowego dla Administracji Ceł i Podatków Pośrednich w sprawie mianowania Michała Joniaka Komisarzem Szczegółowym dla Stwierdzenia Wszystkich Przedmiotów Własności Państwa należących do urzędu celnego w Stęszewie, 21 V $1920 \mathrm{r}$.

${ }^{40}$ Ibidem, Pismo nr I 3408 Głównego Komisarza Szczegółowego dla Administracji Ceł i Podatków Pośrednich w sprawie mianowania Michała Joniaka Komisarzem Szczegółowym dla Stwierdzenia Wszystkich Przedmiotów Własności Państwowej w obrębie Dyrekcji Ceł w Poznaniu, 7 VI 1920 r.

${ }^{41}$ Zbiór umów i uktadów..., s. 44.

${ }^{42}$ APP, DCP, sygn. 15, Pismo 1. dz. 621 Głównej Kasy Celnej do prezydenta Dyrekcji Ceł w Poznaniu, 9 VIII 1920 r. 
się co do rzeczywistego terminu zakończenia rozliczeń. Przewidywano tylko, że przypadnie on najwcześniej na koniec sierpnia $1920 \mathrm{r.}^{43}$

Celnictwo jako dziedzina dotychczasowej kooperacji administracyjnej władz Rzeszy i państw związkowych uległo wskutek niekorzystnych dla strony niemieckiej postanowień finansowych traktatu pokojowego wyraźnej centralizacji zarządu. Moca art. 83 Konstytucji Republiki Weimarskiej z 11 VIII 1919 r. zarząd ceł i podatków konsumpcyjnych przekazano władzom Rzeszy ${ }^{44}$. Choć art. 169 wspomnianej ustawy zasadniczej dawał jeszcze możliwość pozostawienia państwom związkowym zarządu i poboru tych danin na okres przejściowy, jednakże wraz z wejściem w życie Ustawy o zarządzie skarbowym Rzeszy z 10 IX 1919 r. powyższy artykuł konstytucji przestał faktycznie obowiązywać. Zgodnie z $§ 1$ wspomnianej wrześniowej regulacji prawnej naczelne kierownictwo i zwierzchnictwo nad władzami skarbowymi Rzeszy, administrującymi wszystkimi daninami, które całkowicie lub częściowo pobierano na jej rzecz, przysługiwały Ministerstwu Skarbu Rzeszy ${ }^{45}$. Wzmocnienie roli tego ostatniego w całokształcie spraw skarbowych republiki miało również swoje przełożenie na jego pozycje $\mathrm{w}$ kwestiach związanych $\mathrm{z}$ likwidacją niemieckich struktur skarbowych we wschodnich prowincjach państwa.

Na konferencji resortów rządu pruskiego i Rzeszy, odbytej w Berlinie 5 XII 1919 r., ustalono zakres ich uprawnien w sprawach zdawczo-likwidacyjnych na wschodnich obszarach odstapionych. Do decyzji poszczególnych ministerstw pozostawiono przede wszystkim kwestie wyboru i ustanowienia komisarzy szczegółowych i zdawczych swego zakresu działania ${ }^{46}$. Minister skarbu Rzeszy uregulował pierwsza z wymienionych kwestii jeszcze w grudniu 1919 r., ustanawiając komisarzami szczegółowymi dla zdania głównych urzędów celnych kierowników tychże, analogiczne stanowisko powierzył w przypadku każdego samodzielnego urzędu celnego jego naczelnikowi, a na urząd komisarzy szczegółowych odpowiedzialnych za oddanie władzom polskim pozostałych miejscowych urzędów administracji celnej powołał tamtejszych nadkontrolerów celnych $^{47}$. Zgodnie z brzmieniem ostatniego ustępu rozdz. II cz. 1 litery B umowy berlińskiej komisarze szczegółowi zarządu celnego podlegali wyłącznie swej władzy przełożonej za wyjątkiem czynności pośredniczących komisarza państwowego i komisarzy generalnych w sprawach nadzoru służbowego i zdania administracji ${ }^{48}$. W grudniu 1919 r. minister skarbu Rzeszy dokonał również wstępnych nominacji na stanowiska komisarzy zdawczych niemieckiej

${ }^{43}$ Ibidem.

${ }^{44}$ Reichs Gesetz-Blatt 1919, nr 152, poz. 6982.

${ }^{45}$ Ibidem, nr 176, poz. 7042.

${ }^{46}$ APP, St.K., sygn. 60, Niederschrift über die Sitzung der Ost Konferenz vom 5 XII 1919.

${ }^{47}$ Archiwum Państwowe we Wrocławiu (dalej: APWr), Urząd Skarbowy Prowincji Dolnośląskiej we Wrocławiu 1919-1945 (dalej: USPD), sygn. 3243, Pismo nr IV.8777 ministra skarbu Rzeszy do prezydenta Krajowego Urzędu Skarbowego we Wrocławiu, 17 XII 1919 r.

${ }^{48}$ Zbiór umów i uktadów..., s. 29. 
administracji ceł i podatków pośrednich w prowincjach śląskiej, poznańskiej, Prusy Zachodnie i Wschodnie ${ }^{49}$. Mianowanie na wyżej wymieniony urząd z zakresem działania na obszar odstapiony prowincji poznańskiej otrzymał wówczas dotychczasowy zastępca prezydenta Naddyrekcji Ceł w Poznaniu, nadradca rejencyjny Oskar Galleiske ${ }^{50}$. Oficjalna nominacja tego ostatniego na stanowisko komisarza zdawczego przez ministra skarbu Rzeszy nastapiła na początku stycznia 1920 r. Dalsze uchwały wspomnianej konferencji wschodniej pozostawiały do załatwienia zainteresowanym ministerstwom kwestie sporządzenia wzorów protokołów oddania, dostarczenia komisarzom państwowym wykazów komisarzy szczegółowych i zdawczych oraz określenia zakresu zadań tych ostatnich. Uznano za wskazane bezpośrednie porozumiewanie się ministerstw z komisarzami państwowymi w kwestiach odnoszących się do zakresu ich działania, a co do ponoszenia kosztów akcji zdawczej oczekiwano porozumienia organów skarbowych Rzeszy i Prus ${ }^{51}$. Do dalszych prerogatyw ministra skarbu Rzeszy należało monitorowanie przebiegu akcji likwidacyjnej niemieckiego zarządu ceł i podatków pośrednich w prowincji poznańskiej droga raportów służbowych komisarza zdawczego. Do września 1920 r. ze środków budżetowych Ministerstwa Skarbu Rzeszy pokrywano wszelkie koszty działalności badanego komisariatu, po czym obowiązek ten przejął od niego komisarz państwowy w Pile, przeznaczając na ten cel fundusze pruskiego Ministerstwa Skarbu ${ }^{52}$. W kompetencji ministra skarbu Rzeszy leżało także mianowanie urzędników biura zdawczego, zatwierdzanie kandydatur wnoszonych przez komisarza ${ }^{53}$ oraz uregulowanie kwestii przedstawicielstwa pozwanych fiskusów Rzeszy i Prus we wszystkich przynależnych lub będacych jeszcze w toku spraw karnych skarbowych należących do zakresu działania byłej Naddyrekcji Ceł w Poznaniu ${ }^{54}$.

W celu obrony wspólnych interesów rządów pruskiego i Rzeszy przy wykonywaniu traktatu pokojowego, likwidowaniu i przekazywaniu spraw zarządu wewnętrznego, a przy współdziałaniu zastępców właściwych władz także pozostałych gałęzi administracji prowincjonalnej ustanowiono $17 \mathrm{XI}$ 1919 r. komisarzy państwowych (Reichs- und Staatskommissaren für die Überleitung an Polen) ${ }^{55}$. Urząd ten dla okręgów rejencyjnych bydgoskiego

\footnotetext{
${ }^{49}$ APWr, USPD, sygn. 3243, Pismo nr IV.8777 ministra skarbu Rzeszy do prezydenta Krajowego Urzędu Skarbowego we Wrocławiu, 17 XII 1919 r.

${ }^{50}$ Ibidem.

${ }^{51}$ APP, St.K., sygn. 60, Niederschrift über die Sitzung der Ost Konferenz vom 5 XII 1919.

${ }^{52}$ Ibidem, sygn. 30, Odpis pisma F. J. 3575 pruskiego ministra skarbu do Komisarza Zdawczego Niemieckiej Administracji Ceł i Podatków Pośrednich, 9 IX 1920 r.

${ }^{53}$ Ibidem, Pismo nr 11/20 Komisarza Zdawczego dla Niemieckiej Administracji Ceł i Podatków Pośrednich do ministra skarbu Rzeszy w Berlinie, 20 I 1920 r.

${ }^{54}$ Ibidem, Odpis pisma ministra skarbu Rzeszy III P (IV a) 2024 do komisarza państwowego von Bülowa w Pile, 25 VI $1921 \mathrm{r}$.

${ }^{55}$ Ibidem, sygn. 60, Vollmacht Tg. Nr. 561. I, 17 XI 1919 r.
} 
i poznańskiego powierzono dotychczasowemu prezydentowi rejencji bydgoskiej Friedrichowi von Bülowowi, co znalazło następnie potwierdzenie w postanowieniach umowy berlińskiej zawartych w ustępie c) rozdz. I cz. 1 litery B. Jak pokazała niedaleka przyszłość, właściwość terytorialna jego działalności szybko uległa uszczupleniu. W połowie grudnia 1919 r. pruski minister spraw wewnętrznych biorąc pod uwagę geograficzne położenie pięciu południowych powiatów prowincji poznańskiej (kępińskiego, krotoszyńskiego, rawickiego, leszczyńskiego i wschowskiego), wyraził zgodę na ich przekazanie kompetencji komisarza państwowego we Wrocławiu Wolfganga von Jaenickego ${ }^{56}$. Zakres działania von Bülowa unormowany umową berlińska był taki sam, jak w przypadku polskiego komisarza państwowego (przekazanie agend administracyjnych wykraczajacych poza terytorialną właściwość działania komisarzy generalnych, omawianie zagadnień zasadniczych, wyrażanie zgody na dłuższy niż tydzień pobyt niemieckich komisarzy i ich personelu pomocniczego na polskim terytorium w wypadku przedłużenia akcji zdawczej zarządu cywilnego ponad termin wojskowej ewakuacji terenów odstapionych, rozstrzyganie kwestii spornych zaistniałych między obustronnymi głównymi komisarzami szczegółowymi i komisarzami generalnymi $)^{57}$. Bülow odpowiadał ponadto za dostarczenie polskiemu komisarzowi państwowemu zestawienia wszystkich komisarzy zdawczych i podległych im urzędników. Ustalał wspólnie z nim sposób zakwaterowania powyższych funkcjonariuszy i szczegóły akcji zdawczej ${ }^{58}$. W tym pierwszym względzie prowadził bezpośrednie rokowania z polskim komisarzem państwowym w kwestii ulokowania siedziby komisariatu zdawczego niemieckiej administracji ceł i podatków pośrednich. Bülowowi przysługiwało prawo oficjalnego mianowania komisarza zdawczego dla zarządu ceł i podatków pośrednich po podjęciu wiążącej decyzji personalnej przez ministra skarbu Rzeszy ${ }^{59}$. Temu uprawnieniu uczynił on zadość między 13 a 19 I 1920 r., podczas gdy komisarz państwowy we Wrocławiu dokonał nominacji nadradcy Galleiskego na stanowisko komisarza zdawczego dla powiatów rawickiego, leszczyńskiego, wschowskiego i krotoszyńskiego 10 stycznia tego roku ${ }^{60}$. Stosunek służbowy łączący wspomnianego komisarza

${ }^{56}$ APWr, USPD, sygn. 3243, Odpis pisma O.6881 pruskiego ministra spraw wewnętrznych z 16 XII 1919 r.

${ }^{57}$ Zbiór umów i uktadów..., s. 29; APP, DCP, sygn. 15, Pismo l. dz. 327/20 K.P. komisarza państwowego dr. Celichowskiego do prezydenta Naddyrekcji Ceł w Poznaniu dr. Radwańskiego, 22 IV $1920 \mathrm{r}$.

58 Zbiór umów i uktadów..., s. 31.

59 APP, St.K., sygn. 30, Pismo nr 3/20 Komisarza Zdawczego dla Administracji Ceł i Podatków Pośrednich do Komisarza Państwowego dla Odstąpionej Części Prowincji Poznańskiej prezydenta rejencji w Bydgoszczy von Bülowa, 13 I 1920 r.; APWr, USPD, sygn. 3243, Pismo IV.Wa.10389 ministra skarbu Rzeszy do Komisarza Państwowego dla Odstapionych Polsce Części Prowincji Śląskiej i Powiatów Południowo-Poznańskich we Wrocławiu, 5 I 1920 r.

${ }^{60}$ APP, St.K., sygn. 30, Odręczne pismo nr 6 Komisarza Zdawczego dla Administracji Ceł i Podatków Pośrednich do komisarza państwowego von Bülowa w Pile, 14 I 1920 r. 
i Generalne Biuro Zdawcze w Pile (komisarza państwowego) wyglądał analogicznie jak w przypadku komisarzy szczegółowych zarządu celnego i komisarzy państwowych i generalnych, polegając na uznaniu przez tego pierwszego pośredniczącej czynności komisarza państwowego w dziedzinach nadzoru służbowego i oddania administracji ${ }^{61}$. Od września 1920 r. w kompetencji von Bülowa leżało pokrywanie ze środków dostarczanych przez skarb pruski kosztów działalności urzędowej wszystkich komisariatów zdawczych prowincji poznańskiej ${ }^{62}$.

Zasadnicze czynności likwidacyjne niemieckiej administracji celnej w obrębie prowincji poznańskiej wykonywał Szczegółowy Komisarz Zdawczy Niemieckiego Zarządu Ceł i Podatków Pośrednich (Überleitungskommissar für die deutsche Verwaltung der Zölle und indirekten Steuern im gesammten Abtretungsgebiet der Provinz Posen). Rozporządzeniem ministra skarbu Rzeszy z 3 I 1920 r. oficjalne mianowanie na to stanowisko otrzymał dotychczasowy zastępca prezydenta Naddyrekcji Ceł w Poznaniu, nadradca rejencyjny O. Galleiske ${ }^{63}$. Jego siedzibą urzędową w Poznaniu stała się $-\mathrm{z}$ powodu nieugiętego stanowiska władz polskich - plebania parafii ewangelickiej przy ul. Spokojnej 13. Właściwość terytorialna jego działalności wskutek podziału w grudniu $1919 \mathrm{r}$. terytorium byłej prowincji poznańskiej pomiędzy komisarzy państwowych w Pile i Wrocławiu stała się kwestią niejasną i pociagała za sobą pytanie o sposób załatwiania spraw zdawczych niemieckiego zarządu ceł na obszarze wspomnianej prowincji. Bazując bowiem na powyższym podziale terytorialno-kompetencyjnym, zasadne stawało się zapatrywanie, że na terenie prowincji poznańskiej, podległym komisarzowi państwowemu w Pile, czynności likwidacyjne niemieckiego zarządu celnego winien wykonywać komisarz Galleiske, natomiast w pięciu południowych powiatach tej samej prowincji, pozostajacych $\mathrm{w}$ sferze działania komisarza państwowego we Wrocławiu, analogiczne czynności winien wykonywać przedstawiciel Naddyrekcji Ceł we Wrocławiu. Ściśle związana z powyższym stanem rzeczy była kwestia traktowania pod względem zdawczym tych terenów pięciu południowych powiatów prowincji poznańskiej, na których funkcjonowała nadal

${ }^{61}$ APWr, USPD, sygn. 3243, Pismo nr IV.8777 ministra skarbu Rzeszy do prezydenta Krajowego Urzędu Skarbowego we Wrocławiu, 17 XII 1919 r.

${ }^{62}$ Zob. przypis 21.

${ }^{63}$ APP, St.K., sygn. 30, Pismo nr 3/20 Komisarza Zdawczego dla Administracji Ceł i Podatków Pośrednich do komisarza państwowego von Bülowa w Bydgoszczy, 13 I 1920 r.; ibidem, Odpis pisma Komisarza Zdawczego dla Niemieckiej Administracji Ceł i Podatków Pośrednich do Miejskiej Kasy Podatkowej w Poznaniu, 30 I 1920 r. W dokumentacji niemieckiego komisarza państwowego von Bülowa, dotyczącej przekazania władzom polskim administracji celnej badanego obszaru (sygn. 30), nie zachował się akt nominacyjny komisarza Galleiskego z 3 I 1920 r., na który często powołuje się on w swej korespondencji służbowej. W aktach Urzędu Skarbowego Prowincji Dolnoślaskiej we Wrocławiu (sygn. 3243) odnaleziono dokument o mianowaniu tegoż Komisarzem Zdawczym dla Administracji Ceł i Podatków Pośrednich na obszar prowincji poznańskiej z datą 5 I 1920 r. 
niemiecka administracja celna, nie udało się ich opanować Polakom w latach 1918-1919, a zostały przewidziane przez traktat pokojowy do odstapienia Polsce i podlegały kompetencji komisarza państwowego we Wrocławiu. Na kanwie omówionych nieścisłości kompetencyjnych Naddyrekcja Ceł we Wrocławiu wystosowała 25 XII 1919 r. pismo do podwładnych nadinspektorów celnych o podporządkowaniu sobie pod względem zarządu celnego i spraw zdawczych nieopanowanych przez Polskę części obwodów głównych urzędów celnych w Lesznie i Ostrowie Wlkp. ${ }^{64}$ Powyższa kolizję interesów na linii wrocławska naddyrekcja ceł - komisariat zdawczy w Poznaniu rozstrzygną ostatecznie minister skarbu Rzeszy. Pismem IV.Wa.10389 z 5 I 1920 r. określił terytorialną właściwość działania komisarza Galleiskego na cały obszar odstapiony prowincji poznańskiej ${ }^{65}$, po czym kolejnym pismem IV.507. z 13 I 1920 r. potwierdził jego kompetencję także dla południowych powiatów prowincji poznańskiej ${ }^{66}$.

W gestii nadradcy Galleiskego leżało w pierwszym rzędzie mianowanie komisarzy szczegółowych, odpowiedzialnych za przekazanie władzom polskim poszczególnych urzędów administracji celnej ${ }^{67}$. Zgodnie z brzmieniem przepisów zawartych pod litera B cz. 2 rozdz. II ust. a) umowy berlińskiej i w art. 1 Protokołu dodatkowego do polsko-niemieckiego układu o tymczasowym unormowaniu spraw urzędniczych jego kompetencji podlegały sprawy pośrednictwa między władzą polską a podległymi mu urzędnikami w kwestiach sporów na tle ich uczuć narodowych i obowiązków sumienia, przenoszenia na własne żądanie spraw karnych urzędników niemieckich z nadzwyczajnych sądów cywilnych na drogę zwykłego postępowania, pod warunkiem orzeczenia kary aresztu ponad 3 miesiące lub grzywny ponad 3 tys. marek i zwalniania niemieckich urzędników ze służby na żądanie władz polskich ${ }^{68}$. Komisarzowi zdawczemu powierzono zadanie rozpoznania majątku państwowego administracji celnej, przypadającego ostatecznie Polsce i załatwianie spraw związanych z wejściem Polski jako strony w umowy dotyczące jego zakresu działania, zawarte przez państwo niemieckie lub pruskie z uwzględnieniem

${ }^{64}$ APWr, USPD, sygn. 3243, Pismo II b nr 386 B Naddyrekcji Ceł we Wrocławiu do nadinspektorów celnych w Oleśnicy, Głogowie, Lesznie i Żmigrodzie, 25 XII 1919 r.

65 Ibidem, Pismo IV.Wa.10389 ministra skarbu Rzeszy do Komisarza Państwowego dla Odstapionych Polsce Części Prowincji Śląskiej i Powiatów Południowo-Poznańskich we Wrocławiu, 5 I $1920 \mathrm{r}$.

${ }^{66}$ Ibidem, Pismo IV.507 ministra skarbu Rzeszy do prezydenta Krajowego Urzędu Skarbowego - Naddyrekcji Ceł we Wrocławiu, 13 I 1920 r.

${ }^{67}$ APP, St.K., sygn. 30, Pismo nr 183 St.K. komisarza państwowego do komisarza zdawczego nadradcy rejencyjnego Galleiske, 10 I 1920 r.; ibidem, Pismo nr 3/20 Komisarza Zdawczego dla Administracji Ceł i Podatków Pośrednich do Komisarza Państwowego dla Odstapionej Części Prowincji Poznańskiej prezydenta rejencji w Bydgoszczy von Bülowa, Poznań 13 I 1920 r.; ibidem, Wstęp do zespołu akt Reichs- und Staatskommissar für die Überleitung an Polen in Schneidemühl 1919-1944.

${ }^{68}$ Zbiór umów i układów..., s. 13, 18, 31. 
obszarów odstapionych ${ }^{69}$. Do kwietnia 1920 r. odpowiadał za stwierdzenie wszystkich przedmiotów własności lub posiadania państwa znajdujących się na zajętych przez Polskę przed 10 I 1920 r. częściach obszarów odstąpionych prowincji poznańskiej i pieniężne rozliczenie dochodów i wydatków państwowych $^{70}$. W wyniku układu zawartego w czerwcu 1920 r. pomiędzy niemieckimi komisarzami państwowymi z Gdańska, Piły i Kwidzyna a polskim komisarzem państwowym Wiktorem Hinzem, komisarzowi zdawczemu zlecono zadanie sporządzenia wykazu akt koniecznych do dalszego funkcjonowania administracji celnej na obszarach prowincji poznańskiej pozostajaccych przy państwie pruskim i tych podlegajacych na zasadzie wzajemności wymianie ${ }^{71}$. Pismem ministra skarbu Rzeszy z 25 VI 1921 r. nadradca Galleiske został ustanowiony przedstawicielem pozwanych władz skarbowych Rzeszy i Prus we wszystkich sprawach karnych skarbowych, podlegajacych kompetencji byłej Naddyrekcji Ceł w Poznaniu ${ }^{72}$.

Wyszczególnione wyżej zadania realizowano w biurze zdawczym przy pomocy fachowego personelu urzędniczego naddyrekcji ceł. Moca rozporządzeń ministra skarbu Rzeszy z 24 IX i 9 X 1919 r. ustalono wyjściowy stan etatów komisariatu zdawczego na 13 urzędników, w tym 6 rachunkowych, 6 zatrudnionych w wyższej kasie celnej, uwzględniając w nim także radcę celnego Waldemara Heyna, pełniącego obowiązki pełnomocnego zastępcy komisarza Galleiskego, prowadzącego sprawy zdawcze pod nieobecność tego ostatniego $^{73}$. Skompletowanie obsady personalnej biura zdawczego napotkało początkowo trudności związane z ustaleniami art. 3 Układu o tymczasowym unormowaniu spraw urzędniczych. Nakładał on na urzędników niemieckich obowiązek pozostania w służbie polskiej na dotychczas zajmowanych stanowiskach do 31 III 1920 r. włącznie ${ }^{74}$. Po wygaśnięciu tej klauzuli

${ }^{69}$ Ibidem, s. 32; APP, DCP, sygn. 15, Pismo l. dz. 327/20 K.P. komisarza państwowego do prezydenta Naddyrekcji Ceł w Poznaniu, 22 IV 1920 r.

70 APP, DCP, sygn. 15, Pismo l. dz. 327/20 K.P. komisarza państwowego wojewody do prezydenta Naddyrekcji Cła dr. Radwańskiego, 22 IV 1920 r.; ibidem, Wykaz niemieckich głównych komisarzy szczegółowych.

${ }^{71}$ Ibidem, Pismo l. dz. 1328/20 K.P. Komisarza Państwowego dla Przejęcia Zarządu Cywilnego na Odstapionych Polsce Częściach b. Dzielnicy Pruskiej do głównego komisarza szczegółowego prezydenta dyrekcji ceł Radwańskiego w sprawie stwierdzenia akt potrzebnych do dalszego prowadzenia administracji, 20 VII $1920 \mathrm{r}$.

${ }^{72}$ APP, St.K., sygn. 30, Odpis pisma III P (IV a) 2024 ministra skarbu Rzeszy do komisarza państwowego w Pile, 25 VI 1921 r.

${ }^{73}$ Ibidem, Pismo nr 11/20 Komisarza Zdawczego dla Niemieckiej Administracji Ceł i Podatków Pośrednich do ministra skarbu Rzeszy, 20 I 1920 r.; ibidem, Pismo Tgb. nr 11/20 Komisarza Zdawczego dla Niemieckiej Administracji Ceł i Podatków Pośrednich do ministra skarbu Rzeszy w Berlinie, 20 I 1920 r.; ibidem, Pismo nr 2455/20 Komisarza Zdawczego dla Niemieckiej Administracji Ceł i Podatków Pośrednich do komisarza państwowego w Pile, 5 VIII 1920 r.

${ }^{74}$ Zbiór umów i układów..., s. 11. 
stan etatowy komisariatu wynosił w czerwcu 1920 r. 11 urzędników ${ }^{75}$, w tym komisarz zdawczy, jego zastępca, 4 urzędników rachunkowości i 5 wyższej kasy celnej. Skład osobowy biura zdawczego z podaniem tytułów służbowych zatrudnionych w nim funkcjonariuszy państwowych przedstawia tabela 1.

Tab. 1. Skład osobowy Biura Zdawczego Niemieckiej Administracji Ceł i Podatków Pośrednich w czerwcu $1920 \mathrm{r}$.

\begin{tabular}{|c|l|l|}
\hline Lp. & \multicolumn{1}{|c|}{ Imię i nazwisko } & \multicolumn{1}{|c|}{ Tytuł służbowy } \\
\hline 1 & Oskar Galleiske & nadradca rejencyjny, komisarz zdawczy \\
\hline 2 & Waldemar Heyn & nadinspektor celny (radca celny), zastępca komisarza zdawczego \\
\hline 3 & Gustav Leutke & dyrektor rachunkowości \\
\hline 4 & Paul Rohr & rendant wyższej kasy celnej (radca rachunkowości) \\
\hline 5 & Feodor Jänisch & inspektor celny (nadkontroler celny) \\
\hline 6 & Karl Riedel & nadsekretarz celny (radca rachunkowości) \\
\hline 7 & Waldemar Bressel & jw. \\
\hline 8 & Milz & nadsekretarz celny \\
\hline 9 & Eisengruber & jw. \\
\hline 10 & G. Tönsmann & jw. \\
\hline 11 & Hermann Schöfinius & jw. \\
\hline
\end{tabular}

Źródło: APP, St.K., sygn. 62, Nachweisung der bei der Ueberleitungsstelle fuer die deutsche Verwaltung der Zoelle und indirekten Steuern in Posen taetigen Ueberleitungskommissare und Beamten, 12 VI 1920 r.

Jak już wcześniej nadmieniłem, wydatki badanego komisariatu pokrywano do początku września 1920 r. ze środków Ministerstwa Skarbu Rzeszy, a dokładniej krajowych urzędów skarbowych Gross-Berlin i Brandenburgia, po czym wskutek układu między Rzeszą Niemiecką a Prusami te ostatnie wzięły na siebie obowiązek finansowania kosztów działalności wszystkich komisariatów zdawczych na zasadzie zwrotu przez Rzeszę poniesionych nakładów ${ }^{76}$. Zestawienie wydatków opisywanego komisariatu w okresie od $1 \mathrm{X}$ 1919 r. do 31 III 1920 r. z uwzględnieniem kosztów służbowych, rzeczowych i na bieżącą działalność przedstawia tabela 2 .

75 APP, St.K., sygn. 62, Nachweisung der bei der Ueberleitungsstelle fuer die deutsche Verwaltung der Zoelle und indirekten Steuern in Posen taetigen Ueberleitungskommissare und Beamten, 12 VI 1920 r.

${ }^{76}$ Ibidem, sygn. 30, Odpis pisma nr F.J.3575 pruskiego ministra skarbu do Komisarza Zdawczego dla Niemieckiej Administracji Ceł i Podatków Pośrednich, 9 IX 1920 r. 
Tab. 2. Ogólne zestawienie wydatków Biura Zdawczego Niemieckiej Administracji Ceł i Podatków Pośrednich w okresie od 1 X 1919 r. do 31 III 1920 r.

\begin{tabular}{|l|c|}
\hline \multicolumn{1}{|c|}{ Rodzaj wydatku } & Suma w markach \\
\hline Służbowe $^{77}$ & 247500 \\
\hline Rzeczowe $^{78}$ & 127810 \\
\hline Szacowana wartość opłat $^{\prime}$ & 15000 \\
\hline Koszty działalności służbowej & \\
\hline Ogółem & 68590 \\
\hline
\end{tabular}

Źródło: APP, St.K., sygn. 30, Nachweis der Ausgaben für die Überleitungsstelle der deutschen Zollverwaltung im gesamten Abtretungsgebiet der Provinz Posen.

Z dniem 1 X 1920 r. Biuro Zdawcze Niemieckiej Administracji Ceł i Podatków Pośrednich zostało przeniesione z Poznania do Berlina i znajdowało się przy Judenstrasse $58 / 60^{80}$, po czym w czerwcu 1921 r. mieściło się już przy Friedrichstrasse $107^{81}$.

W wyniku przeprowadzonej w kwietniu 1920 r. decentralizacji w wykonywaniu zadań komisarzy zdawczych główny komisarz szczegółowy dla administracji ceł, nadinspektor celny Borgmann otrzymał w ślad za swoim polskim odpowiednikiem zadania stwierdzenia przedmiotów własności lub posiadania państwa występujących w częściach terytoriów odstapionych prowincji poznańskiej, zajętych przez Polskę przed 10 I 1920 r., i pieniężnego rozliczenia dochodów i wydatków państwowych na tychże obszarach ${ }^{82}$.

77 Wydatki służbowe obejmują: dochody nadradcy Galleiskego za rok rachunkowy 1920 w kwocie 32700 marek i 6100 marek dodatków urzędniczych, dochody dyrektora rachunkowości Leutkego za rok rachunkowy 1920 w wysokości 23850 marek oraz rendanta wyższej kasy celnej Rohra za rok rachunkowy 1920 w kwocie 23850 marek, ekwiwalenty dla urzędników biura zdawczego 151000 marek, koszty podróży i diety służbowe 10000 marek; ibidem, Nachweis der Ausgaben für die Überleitungsstelle der deutschen Zollverwaltung im gesamten Abtretungsgebiet der Provinz Posen.

${ }^{78}$ Wydatki rzeczowe obejmuja: zakup samochodu służbowego 83000 marek, zakup przynależnych środków obrotowych 44810 marek, ibidem.

${ }^{79}$ W skład kosztów działalności służbowej wchodzą: koszty pisarskie 6000 marek, sprzęty służbowe 3600 marek, czynsz 6000 marek, ogrzewanie i oświetlenie 3000 marek, wynagrodzenia pisarskie 1000 marek, pomocnicy biurowi i szofer wraz ze składkami starcza, inwalidzką i kasy chorych 21600 marek, porto i opłaty telegraficzne 2000 marek, wydatki mieszane 390 marek, utrzymanie i prowadzenie samochodu 25000 marek; ibidem.

${ }^{80}$ Ibidem, Pismo nr 2984 Komisarza Zdawczego dla Niemieckiej Administracji Ceł i Podatków Pośrednich do komisarza państwowego w Pile, 28 IX 1920 r.

${ }^{81}$ Ibidem, Odpis pisma III P (IV a) 2024 ministra skarbu Rzeszy do komisarza państwowego von Bülowa w Pile, 25 VI 1921 r.

82 APP, DCP, sygn. 15, Pismo l. dz. 327/20 K.P. komisarza państwowego do prezydenta Naddyrekcji Ceł w Poznaniu, 22 IV 1920 r.; ibidem, Wykaz niemieckich głównych komisarzy szczegółowych. 
Borgmann pełnił jednocześnie obowiązki komisarza szczegółowego dla przekazania władzom polskim Głównego Urzędu Celnego w Bydgoszczy, gdzie ze względu na niemożność pokrycia kosztów jego zdania ze środków tamtejszej kasy celnej, obciażanie zdawczej korespondencji pocztowej portem oraz przewidywane odejście ze służby, prosił komisarza państwowego na początku kwietnia 1920 r. o zgodę na zorganizowanie biura likwidacyjnego i powierzenie mu jego kierownictwa ${ }^{83}$. Jako personel pomocniczy proponował mianować sekretarza celnego Hermanna Richtera, asystenta celnego Bertholda Griebenowa i dozorce celnego Schulza ${ }^{84}$. Jego prośba w tej samej sprawie, skierowana uprzednio do komisarza zdawczego, znalazła jego aprobate 30 III 1920 r. i skutkowała mianowaniem Borgmanna na urząd komisarza szczegółowego niemieckiego zarządu ceł $\mathrm{z}$ dniem 1 kwietnia tego roku ${ }^{85}$. Podobne stanowisko do wniosku nadinspektora zajął także komisarz państwowy von Bülow, mianując go na początku kwietnia $1920 \mathrm{r}$. zastępca komisarza zdawczego do spraw likwidacji i zdania Głównego Urzędu Celnego w Bydgoszczy ${ }^{86}$.

Akcję przejmowania niemieckiej administracji ceł i podatków pośrednich zapoczątkowano na obszarze byłej prowincji poznańskiej, przyznanym Polsce $\mathrm{z}$ chwila ratyfikacji traktatu pokojowego już w styczniu $1920 \mathrm{r} \cdot{ }^{87}$ Najprawdopodobniej były to działania doraźne lub podyktowane potrzebą chwili, gdyż zarówno po stronie polskiej, jak i niemieckiej urzędy państwowe przewidziane do wypełniania tych zadań znajdowały się dopiero w początkowym stadium organizacji. Szczegółowy przebieg wspomnianej na wstępie tego akapitu działalności ilustrują zachowane w zespole akt Dyrekcji Ceł w Poznaniu protokoły zdawczo-odbiorcze. Ich analiza wskazuje, że w okresie od lutego do kwietnia 1920 r. nie podejmowano żadnych działań w tej materii, co zapewne wiązało się $\mathrm{z}$ dalszym trwaniem procesu organizacyjnego instytucji przeznaczonych do wykonywania opisywanych czynności. Początek planowej i obustronnie skoordynowanej akcji zdawczo-odbiorczej przypadł na pierwszą połowę maja 1920 r. Dziesiątego dnia tego miesiąca doszło do spotkania polskiego i niemieckiego pełnomocnika we Wronkach, gdzie dokonano przejęcia tamtejszej nadkontroli celnej i własności miejscowego urzędu celnego ${ }^{88}$. W kolejnych dniach maja objęto $\mathrm{w}$ polskie posiadanie ruchomy i nieruchomy majątek

${ }^{83}$ Ibidem, St.K, sygn. 30, Pismo No A.10 nadinspektora celnego Borgmanna do komisarza państwowego w Bydgoszczy, 3 IV 1920 r.

${ }^{84}$ Ibidem.

${ }^{85}$ Ibidem, Telegram nr 29/26 komisarza zdawczego Oskara Galleiske do nadinspektora celnego Borgmanna, 30 III $1920 \mathrm{r}$.

${ }^{86}$ Ibidem, Pismo nr 1427 St.K. komisarza państwowego w Bydgoszczy do nadinspektora celnego Borgmanna, 7 IV 1920 r.

${ }^{87}$ APP, DCP, sygn. 15, Protokoły przejęcia urzędów celnych w Międzychodzie i Wieleniu, 22 I 1920 r.; ibidem, Spis dóbr i własności pruskich fiskalno-celnych w Kępnie, 24 I 1920 r.; ibidem, Protokół zdania gorzelni w Jabłonnej, podpisany w Górze Śląskiej 22 I 1920 r.

${ }^{88}$ Ibidem, sygn. 104, Odpis protokołu przejęcia Urzędu Celnego i Nadkontroli Celnej we Wronkach wraz z odpisami inwentarzy własności celnej, $10 \mathrm{~V} 1920 \mathrm{r}$. 
państwowy urzędów i nadkontroli celnych w Szamotułach (11 maja), Gnieźnie (18 maja) i Stęszewie (21 maja), zaś w Buku 17 maja strona niemiecka przekazała polskiej władzy celnej własność miejscowego urzędu i dozoru celnego $^{89}$. Nie zachowała się żadna dokumentacja aktowa dotycząca Urzędu Celnego w Środzie Wlkp., który w świetle korespondencji urzędowej miał być przejęty również w maju $1920 \mathrm{r} \cdot{ }^{90}$

W okresie 9-24 VI 1920 r. częściowo stwierdzono i przejęto państwowa własność celną w obwodach głównych urzędów celnych w Lesznie (Urząd Celny w Śmiglu i nadkontrole w Koźminie i Śmiglu), Inowrocławiu (główny urząd celny i nadkontrola), Rogoźnie (urzędy celne i nadkontrole Murowana Goślina, Skoki, Wagrowiec, budynek dozorców celnych w Skokach) oraz Wrześni (Urząd Celny i Nadkontrola Celna w Jarocinie) ${ }^{91}$.

W lipcu 1920 r. przeprowadzono czynności zdawczo-odbiorcze przy 18 urzędach, 15 nadkontrolach oraz 45 dozorach celnych położonych w obwodach głównych urzędów w Ostrowie Wlkp., Inowrocławiu i Wrześni.

W okresie 7-28 VIII 1920 r. objęto w polskie posiadanie państwową własność celną występująca w obwodach głównych urzędów celnych w Lesznie (urzędy i nadkontrole celne Gostyń, Kościan, Śrem oraz Nadkontrola Celna Czempin), Ostrowie Wlkp. (urzędy celne Skalmierzyce Łańcuch i Nowe Skalmierzyce Dworzec wraz z cała miejscową infrastruktura celna), Poznaniu (urzędy i nadkontrole celne Grodzisk, Lwówek, Pniewy i Wolsztyn oraz budynki dozorców celnych we Lwówku i Opalenicy) oraz Rogoźnie (Urząd Celny i Nadkontrola Celna w Czarnkowie, Główny Urząd Celny i Nadkontrola Celna w Rogoźnie) ${ }^{92}$. Ponadto 30 VIII 1920 r. doszło do przejęcia gmachu

${ }^{89}$ Ibidem, Odpisy protokołów przejęcia i inwentarzy własności celnej w Szamotułach, Gnieźnie, Stęszewie i Buku.

${ }^{90}$ Zob. przypis 39.

${ }^{91}$ APP, DCP, sygn. 150, Odpis protokołu przejęcia Nadkontroli Celnej w Koźminie wraz z odpisami inwentarzy rzeczy ruchomych i nieruchomych, 9 VI 1920 r.; ibidem, Odpis protokołu przejęcia Urzędu Celnego i Nadkontroli Celnej w Śmiglu wraz z inwentarzami dóbr ruchomych, 15 VI 1920 r.; ibidem, sygn. 146, Odpis protokołu przejęcia Głównego Urzędu Celnego i Nadkontroli Celnej w Inowrocławiu z załączonymi inwentarzami rzeczy ruchomych, 24 VI 1920 r.; ibidem, sygn. 151, Odpis protokołu przejęcia Urzędu Celnego i Nadkontroli Celnej w Murowanej Goślinie wraz z inwentarzami rzeczy ruchomych, 11 VI 1920 r.; ibidem, Odpis protokołu przejęcia Urzędu Celnego, Nadkontroli Celnej i budynku dozorców celnych w Skokach z dołączonymi inwentarzami własności ruchomej, 11 VI 1920 r.; ibidem, Niemiecko i polskojęzyczny protokół przejęcia Urzędu Celnego i Nadkontroli Celnej w Wagrowcu wraz z inwentarzem rzeczy ruchomych, 11 VI 1920 r.; ibidem, sygn. 158, Odpis protokołu przejęcia Urzędu Celnego i Nadkontroli Celnej w Jarocinie z załączonymi odpisami inwentarzy rzeczy ruchomych, 9 VI $1920 \mathrm{r}$.

92 Ibidem, sygn. 150, Protokół przejęcia Nadkontroli Celnej w Czempiniu wraz z inwentarzem rzeczy ruchomych, 10 VIII 1920 r.; ibidem, Protokół przejęcia Urzędu Celnego i Nadkontroli Celnej w Gostyniu z dołaczonymi inwentarzami rzeczy ruchomych, 10 VIII 1920 r.; ibidem, Protokół przejęcia własności ruchomej należącej do Urzędu Celnego i Nadkontroli Celnej w Kościanie z załączonymi inwentarzami, 28 VIII 1920 r.; ibidem, Protokół przejęcia 
dyrekcji ceł z przynależnym majątkiem ruchomym i nieruchomym, ruchomości znajdujących się w głównej kasie celnej, Głównym Urzędzie Celnym w Poznaniu, tamtejszym Urzędzie Opłat Stemplowych i Podatku Spadkowego oraz poznańskiej nadkontroli celnej ${ }^{93}$.

W dniu 11 IX 1920 r. strona polska przejęła ruchomą własność celna znajdująca się w Urzędzie Celnym i Nadkontroli Celnej w Mogilnie (obwód Głównego Urzędu Celnego w Inowrocławiu) ${ }^{94}$.

Natomiast w październiku 1920 r. likwidowano jeszcze niemiecką administrację celną w obwodach głównych urzędów celnych w Bydgoszczy (urzędy i nadkontrole celne Kcynia i Łabiszyn oraz Urząd Celny w Szubinie), Inowrocławiu (urząd, nadkontrola i posterunek celny w Żninie) oraz Poznaniu (urzędy i nadkontrole celne Pobiedziska i Swarzędz oraz Kolejowy Urząd Celny w Poznaniu ${ }^{95}$. Co do dalszych kierunków działań komisarzy szczegółowych brak jakichkolwiek informacji źródłowych.

własności ruchomej należącej do Urzędu Celnego i Nadkontroli Celnej w Śremie, 10 VIII 1920 r.; ibidem, sygn. 149, Protokół przejęcia własności ruchomej należącej do Dworcowego Urzędu Celnego w Skalmierzycach wraz z dwujęzycznymi inwentarzami rzeczy ruchomych, 24 VIII 1920 r.; ibidem, Protokół przejęcia dwóch budynków dozorców celnych w Skalmierzycach, 24 VIII 1920 r.; ibidem, Protokół przejęcia Urzędu Celnego i budynku dozorców celnych w Skalmierzycach z dołączonym inwentarzem rzeczy ruchomych, 24 VIII 1920 r.; ibidem, Protokół przejęcia dwóch budynków asystentów celnych i budynku dozorców celnych w Skalmierzycach, 24 VIII 1920 r.; ibidem, Protokół przejęcia głównego budynku mieszkalnego, budynku asystentów celnych, budynku stróża celnego i budynku woźnego w Skalmierzycach, 24 VIII 1920 r.; ibidem, sygn. 104, Protokoły przejęcia Urzędu Celnego i Nadkontroli Celnej w Grodzisku włącznie z inwentarzami rzeczy ruchomych, 7 VIII 1920 r.; ibidem, Protokół przejęcia Urzędu Celnego i Nadkontroli Celnej we Lwówku z dołączonymi inwentarzami rzeczy ruchomych, 17 VIII 1920 r.; ibidem, Odpis protokołu przejęcia budynku dozorców celnych we Lwówku, 17 VIII 1920 r.; ibidem, Protokół przejęcia budynku dozorców celnych w Opalenicy, 7 VIII 1920 r.; ibidem, Odpis protokołu przejęcia Urzędu Celnego i Nadkontroli Celnej w Pniewach z dołączonymi inwentarzami rzeczy ruchomych, 17 VIII 1920 r.; ibidem, Protokół przejęcia Urzędu Celnego i Nadkontroli Celnej w Wolsztynie z dołączonymi inwentarzami rzeczy ruchomych, 7 VIII 1920 r.; ibidem, sygn. 151, Odpis protokołu przejęcia Urzędu Celnego i Nadkontroli Celnej w Czarnkowie z dołączonymi inwentarzami rzeczy ruchomych, 3 VIII 1920 r.; ibidem, Odpis protokołu przejęcia Głównego Urzędu Celnego i Nadkontroli Celnej w Rogoźnie z dołączonymi dwujęzycznymi inwentarzami rzeczy ruchomych, 3 VIII $1920 \mathrm{r}$.

${ }^{93}$ Ibidem, sygn. 17, Odpis protokołu przejęcia własności państwowej należącej do Dyrekcji Ceł w Poznaniu z dołączonym inwentarzem dyrekcji ceł do nr 3. protokołu głównego, 30 VIII 1920 r.; ibidem, Inwentarz Głównej Kasy Celnej do nr 3-go protokołu głównego, 30 VIII 1920 r.; ibidem, Inwentarz Głównego Urzędu Celnego w Poznaniu do nr 4-go protokołu głównego, 30 VIII 1920 r.; ibidem, Protokół przejęcia własności ruchomej należącej do Urzędu Opłat Stemplowych i Podatku Spadkowego w Poznaniu, 30 VIII 1920 r.

${ }_{94}$ Ibidem, sygn. 146, Protokół przejęcia własności ruchomej Urzędu Celnego i Nadkontroli Celnej w Mogilnie z dołączonymi inwentarzami majątku ruchomego, 11 IX $1920 \mathrm{r}$.

95 Ibidem, sygn. 113, Protokół przejęcia własności ruchomej należącej do Urzędu Celnego i Nadkontroli Celnej w Kcyni wraz z dołaczonymi inwentarzami, 26 X 1920 r.; ibidem, Protokół przejęcia własności ruchomej należącej do Urzędu Celnego i Nadkontroli Celnej 
Procedura zdania i przejęcia państwowej własności celnej przebiegała w każdym poszczególnym przypadku według jednego, określonego schematu. Po przybyciu na miejsce zastępców komisarza zdawczego - radcy celnego Waldemara Heyna lub nadsekretarza celnego Hermanna Schöfiniusa i Głównego Komisarza Szczegółowego dla Administracji Ceł i Podatków Pośrednich komisarza szczegółowego Michała Joniaka - koniecznym warunkiem wstępnym dla wszczęcia postępowania zdawczo-odbiorczego było wzajemne uznanie pełnomocnictw. Po jego spełnieniu dokonywano pisemnego stwierdzenia miejscowej własności celnej obejmującej przedmioty ruchome i nieruchomości. Pomoca w określeniu kompletnego stanu posiadania poszczególnych urzędów administracji celnej i wyszczególnieniu późniejszych braków w ich ruchomym wyposażeniu służyły niemieckie zwoje przynależności (Beilassrollen) lub dostępne spisy inwentarza ${ }^{96}$. Jednakże w wielu przypadkach nie sposób było określić uprzedniego stanu inwentarzowego przejmowanych urzędów, ponieważ często bywały one całkowicie opróżniane przez urzędników niemieckich z wszelkiej dokumentacji własnościowej i sprzętów użytku celnego jeszcze przed ich objęciem w polskie posiadanie ${ }^{97}$. Innymi szeroko stosowanymi przez Niemców praktykami było przenoszenie ruchomego dobytku celnego z jednego urzędu do drugiego lub wcześniejsze rozgrabianie go na miejscu ${ }^{98}$. Te wszystkie okoliczności sprawiły, że własność państwowa ujęta w protokołach bywała często niekompletna i w dużym stopniu odbiegała od wcześniejszych realiów. Dalszym krokiem opisywanej procedury było obejście przez pełnomocników nieruchomości i dokonanie oceny ich stanu technicznego, ze szczegółowym wykazaniem w protokołach wszelkich usterek budowlanych. W podobny, drobiazgowy sposób badano i odnotowywano stan zachowania ruchomej własności celnej przejmowanej w urzędach, których gmachy stanowiły własność

w Łabiszynie wraz z załączonymi inwentarzami, 26 X 1920 r.; ibidem, Protokół przejęcia własności ruchomej należącej do Urzędu Celnego w Szubinie wraz z załączonym inwentarzem, 26 X 1920 r.; ibidem, sygn. 146, Protokół przejęcia własności ruchomej należącej do Urzędu Celnego i Nadkontroli Celnej w Żninie z dołączonymi inwentarzami, 26 X 1920 r.; ibidem, sygn. 17, Protokół przejęcia własności ruchomej należącej do Urzędu Celnego na dworcu w Poznaniu z dołączonym inwentarzem, 4 X 1920 r.; ibidem, sygn. 104, Protokół przejęcia własności ruchomej należącej do Urzędu Celnego i Nadkontroli Celnej w Pobiedziskach z załączonymi inwentarzami; 7 X 1920 r.; ibidem, Protokół przejęcia własności ruchomej należącej do Urzędu Celnego i Nadkontroli Celnej w Swarzędzu wraz z dołączonymi inwentarzami, 7 X $1920 \mathrm{r}$.

${ }^{96}$ Ibidem, DCP, sygn. 15, Pismo No. II.3927 dyrekcji ceł do Głównego Urzędu Celnego w Poznaniu, 27 IX 1920 r. Zwoje przynależności były wykazami kompletnego wyposażenia danej instytucji celnej w czasie ich sporządzenia.

${ }_{97}$ Ibidem, Kopia pisma 1. dz. 7b 5695/20 Departamentu Skarbu Ministerstwa Byłej Dzielnicy Pruskiej do Ministerstwa Spraw Zagranicznych w Warszawie, 26 VII 1920 r.; ibidem, sygn. 146, Odpis pisma nr 403 Urzędu Celnego I klasy w Gnieźnie w sprawie zabranych tutaj rzeczy pochodzących z Urzędu Celnego w Anastazewie, 21 V 1920 r.

${ }^{98}$ Ibidem, sygn. 15, Pismo No. I.5324 prezydenta Dyrekcji Ceł w Poznaniu do komisarza zdawczego w Poznaniu, 7 IX 1920 r. 
prywatna, lub innego podmiotu administracyjnego, np. kolejowego. Dopiero po spełnieniu tych wszystkich czynności następowało właściwe przejęcie majątku celnego przez polskiego komisarza, połączone z pisemnym wyszczególnieniem w protokołach wszystkich obiektów nieruchomych i przedmiotów ruchomych podlegających przejęciu. W miejscowościach, gdzie oprócz urzędów celnych funkcjonowały także inne instytucje zarządu celnego jak nadkontrole lub dozory celne, dokonywano ich przejęcia tego samego dnia i przy zachowaniu tych samych zasad. Protokoły sporządzano w dwóch równobrzmiących egzemplarzach, zarówno po polsku, jak i po niemiecku. Akcja likwidacyjna niemieckiej administracji celnej znalazła swój finał na obszarze byłej prowincji poznańskiej opanowanym przez władze polskie przed wejściem w życie postanowień traktatu wersalskiego z końcem stycznia $1921 \mathrm{r} .{ }^{99}$

\section{Streszczenie}

Zgodnie z obowiązująca w prowincji poznańskiej od 1908 r. organizacją celnictwa zarząd prowincjonalny prowadziła naddyrekcja ceł, a podlegały jej w terenie główne urzędy celne, urzędy celne I i II klasy oraz inne, lokalne organy kontrolno-poborowe. Traktat wersalski doprowadzając do zmiany przynależności państwowej większości ziem byłego zaboru pruskiego, dostarczył odrodzonej Polsce instrumentów prawnych do budowy własnej administracji celnej. Jednym z nich był art. 256 upoważniający państwa sukcesyjne do przejęcia majątku państwowego Rzeszy i państw niemieckich, znajdującego się na obszarach odstapionych przez nie. Techniczną stronę wykonania powyższego postanowienia na obszarze byłej dzielnicy pruskiej regulowała w głównej mierze polsko-niemiecka Umowa o oddaniu zarządu cywilnego z 25 XI 1919 r. Akcja przejmowania państwowej własności celnej, zainicjowana w styczniu 1920 r. na obszarze byłej prowincji poznańskiej przyznanym Polsce z chwila ratyfikacji traktatu pokojowego, zakończyła się na jej terytorium zajętym przez władze polskie w latach 1918-1919 z końcem stycznia 1921 r.

Geneza administracji celnej II Rzeczypospolitej jest zagadnieniem dotychczas zupełnie nieznanym w polskiej historiografii. Choć niniejszy artykuł dotyczy tylko fragmentu tak rozległego zagadnienia, zarówno pod względem terytorialnym, jak i złożoności całego zjawiska, pozwala jednak uchwycić mechanizm powstawania rodzimych struktur celnych już u ich zarania i stanowi podstawę do analizy późniejszych kierunków działań organizacyjnych władz II Rzeczypospolitej, stawiających sobie za cel unifikację aparatu celnego na obszarze całego odrodzonego państwa.

\section{The takeover of the customs administration in Poznań province in 1920-1921}

From 1908 on, the customs system of Poznan province was administered by the head office of customs, which supervised main customhouses, customhouses of the first and second class, and other local customs clearance posts. The Treaty of Versailles, transferring a large part of the former territory of the Prussian partition to Poland, at the same time gave to the reborn Poland legal instruments necessary to build the own customs administration. One of those tools was the article 256 of the Treaty of Versailles, under which the states to which

${ }^{99}$ Ibidem, Notatka o sprawdzeniu i przejęciu państwowego majątku fiskusa celnego w obrębie Dyrekcji Ceł w Poznaniu, 28 I 1921 r. 
German territory was ceded, acquired all property and possessions situated therein belonging to the German Empire or to the German States. The technical part of this resolution for the former Prussian partition was regulated mainly by the Polish-German Agreement ceding the civilian administration signed in Berlin on 25 November 1919. The action of taking over the state customs properties, initiated in Poznań province in January 1920 at the moment of ratification of the peace treaty, was concluded by the end of January of the following year.

The genesis of the customs administration of the Second Polish Republic has been totally neglected in the Polish historiography. And although the present essay addresses only a certain fragment of the broad phenomenon, both as regards its territory and its complexity, it nevertheless makes it possible to grasp the mechanism of development of Polish customs structures at the very beginning, while at the same time is a good starting point for further study of organisational activities of the government of the Second Polish Republic, which sought to unify the whole customs apparatus throughout the whole territory of the reborn Poland.

\section{Bibliografia}

Handbuch der Provinz Posen, Dritte Ausgabe, Posen 1909.

Ksiega pamiatkowa polskiej administracji skarbowej $w$ Wielkopolsce i na Pomorzu, cz. 1, red. S. Obrzud, Poznań-Grudziądz 1929.

Szczawiński Z., Likwidacja majatków niemieckich w Polsce, Warszawa 1923.

Zbiór umów i układów zawartych między rzadem polskim i niemieckim $w$ Berlinie $i$ w Paryżu w roku 1919 i w styczniu 1920, Poznań 1920.

Bi o g r a m: Andrzej Tamborski - magister historii, absolwent Instytutu Historii Uniwersytetu Wrocławskiego. Od 2012 r. uczestnik Stacjonarnych Studiów Doktoranckich Nauk Historycznych na Wydziale Nauk Historycznych i Pedagogicznych Uniwersytetu Wrocławskiego. Autor kilku artykułów naukowych dotyczących dziejów i działalności polskiej administracji celnej w okresie międzywojennym. Jego zainteresowania badawcze dotyczą skarbowości i służb bezpieczeństwa publicznego II Rzeczypospolitej oraz dziejów ochrony granic państwa polskiego. E-mail: andrzej8622@wp.pl. 